\title{
Monetarism, Keynesianism and the Institutional Status of Central Banks
}

Paavo Uusitalo

University of Helsinki

\begin{abstract}
The paper challenges the belief that economic realty is perceived and economic policy formulated solely on the basis of the state of the economy and the trends within it. Taken into account are the characteristics of the social institutions responsible for following economic development and for taking measures to control the economy themselves or through their authorized recommendations to other institutions within the social system. The institutional and historical material used in this paper covers the four major Nordic countries. The discussion focuses on the status of the central banks, especially their relation to government and parliament, and concludes (1) that central bank status varies greatly between the Nordic countries, and (2) that the autonomous status of the central bank appears to correlate with monetarist features of economic policy. Central banks have less autonomy in the more 'Keynesian' Scandinavian countries, Sweden and Norway, where Keynesianism is often connected with strong and long-term social democratic rule. The genesis of the structural status of the different central banks cannot be explained by the strength of social democracy. Present differences in the structural status of the Scandinavian central banks existed as early as the nineteenth century, long before social democracy began to play a role in the government policy of any Scandinavian country or before the birth of Keynesianism as an economic doctrine.
\end{abstract}

\section{Introduction}

The subject of this paper, examining the choice of methods used by the state to guide the economy in late capitalism, came about by empirical observations of the differences in the economic policies of the four Nordic countries. These differences can be characterized in terms of Keynesian versus monetarist approaches to economic policy. Budget deficits and surpluses, in addition to some of the measures taken by the central banks in pursuit of their monetary policies, will be used as indicators of the different reactions of the Nordic country imbalances within the international economy, especially in the 1970's.

The government and the central bank are the main state institutions directly responsible for economic policy. Structural position and the relationships of these state institutions to each other will be used to explain how economic development is perceived and interpreted, and the way policy measures are recommended and applied. A comparative survey of the legislation defining the status and duties of 
the central banks of the four Nordic countries, especially their degree of autonomy in relation to government and parliament, will be used in this part of the paper. Juridical and historical references, as well as the autobiographies and memoirs of leading central bank executives, will also be used.

The theoretical ideas behind this paper originate mainly within the field of sociology of knowledge and the discussion of the status of the central banks and their relationship to the state raises questions concerning the relevance of unique historical events to sociological research.

\section{Status of the Scandinavian central banks}

The central banks are responsible for controlling the system of money and credit. Though an instrument of the government, the status of the central banks has traditionally been somewhat autonomous. This has been to help protect them from the temptation it is for governments to finance their policy through inflationary measures. The autonomy of the central banks can conflict with the pursuit of an integrated economic policy, however, and as a result the general tendency in developed capitalist countries has been a lessening of the autonomy of the central banks.

When evaluating the relative autonomy of the central banks in relation to the government and to parliament, the following questions arise: Who appoints the members of the central organs of the central bank? To whom are the members of the central organs responsible and how long is their term of office? What possibilities are there for terminating a member's term of office (does a vote of no confidence from parliament result in a member's departure)?

The central banking systems of the Scandinavian countries possess two organs of crucial importance in the formulation of monetary policy: The Board of Management, which prepares and often actually decides on exchange rates, interest rates, and loan policies, and secondly the Bank Supervisors, who represent the immediate political control of the central bank. The appointment and supervision of the members of these two bodies vary considerably between each of the Nordic countries.

\section{Denmark}

In Denmark, the 1936 Central Bank Act establishing formal parliamentary supervision, constituted a compromise between the bourgeois and social democratic viewpoints, the former having argued for a central bank totally independent of the other state bodies.

In the Danish system, the Bank Supervisors constitute an organ which employs both parliamentary and corporative representation. Of a total of 25 members eight are members of parliament, two are appointed by the Ministry of Trade, Industry and Maritime Affairs - 15 are appointed on the basis of their position as experts on the country's economic situation ('indgaende indsigt i erhvervsforhold') and represent both the employers and employees. According to Danish legislation, even regional interests have to be taken into account in the composition of this latter group. The Bank Supervisors appoint these 15 members; three of them are re-elected annually.
The two government-appointed members together with five members elected by the Bank Supervisors form a board constituting the working organ of the Supervisors. Governmental control of the Danish Central Bank is further affirmed by a post referred to as the Bank Commissioner (bankkomissaer). The Minister of Trade, Industry and Maritime Affairs assumes the role of Bank Commissioner and acts as chairman at meetings of the Bank Supervisors. The Bank Commissioner has also to be present at meetings of the management of the Bank Supervisors (bestyrelsen) when crucial issues in monetary policy are being handled.

Actual leadership of the bank is in the hands of the Board of Management. This consists of three directors, two of whom are elected by the Bank Supervisors while one appointed by the King (the government) acts as president of the Board. All three directors have a tenure position until retirement at 70 (Lov nr 116 af 7.4.1936 Hurwitz - von Eyben 1972:2187, von Eyben, Skovgaard 1983:2356-2357, Olsen 1962:273-274, Svendsen, Hansen, Hoffmayer 1968:212-224).

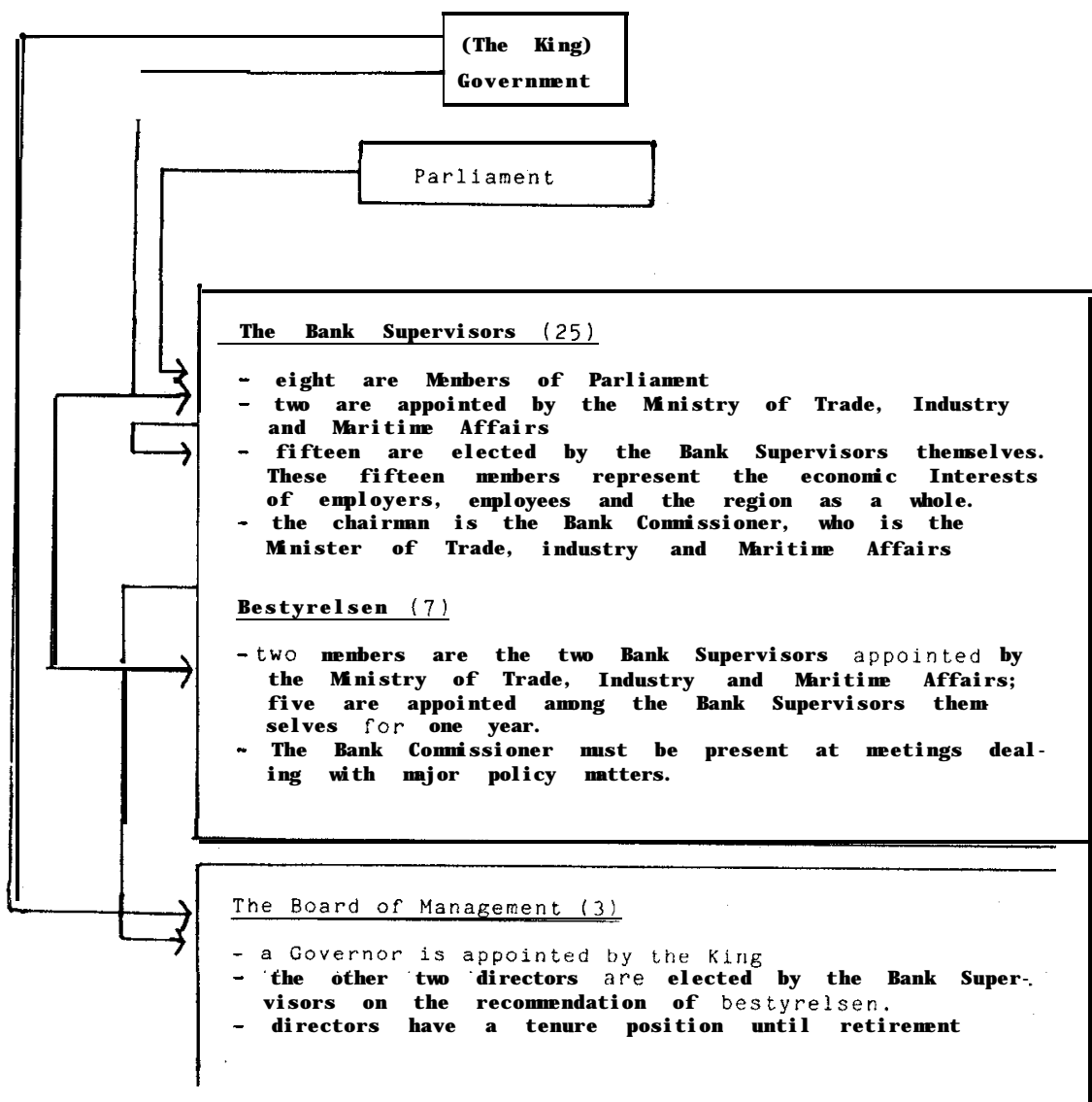

Fig. 1. The Central Bank in relation to the main political institutions in Denmark, 
The juridical position of the Danish Central Bank is very autonomous. Parliamentary control is weak. The Board of Management very often makes independent decisions on Danish monetary policy and its autonomy has periodically been the subject of ardent political discussion in Denmark (f.i. Olsen 1962:274, Finansministeriet 1956:16-17, Svendsen, Hansen, Olsen, Hoffmeyer 1968).

\section{Finland}

In addition to carrying out the normal functions of a central bank, the Bank of Finland, has held a unique position in the very structuring of the State of Finland. After seven hundred years of Swedish rule, Finland became an autonomous grand duchy of the Russian empire as a result of the Napoleonic wars in 1809 and gained full independence after the October Revolution in 1917. When considering the economic structure as opposed to the political institution the picture is somewhat different.

As opposed to Russia, Finland's autonomy at the end of the nineteenth century was based on an earlier capitalist economic development. Finland could exploit both West European and Russian markets and sheltered itself from the more backward and imbalanced Russian economy by employing different protectionist means. Creating its own independent monetary system divorced from the Russian ruble economy, was one of the most central means in this policy. Finland established its markka in 1860 before Sweden established its crown or Germany its mark. After 1865 the Russian ruble was not in practice a means of payment in Finland at all' (Asp 1898; Schybergson 1914; Pipping 1961; Waris 1977). Economically it could be claimed that Finland did not achieve its independence in 1917, but in 1860 when the country established its own currency.

It is commonly accepted in Finnish political history that the strong presidency and stipulated majority rules in parliament are due to the winning bourgeois policies after the civil war in 1918 restricting the power of parliament, As part of this political tendency, the position of the central bank was strengthened in relation to the government and parliament. In 1925-26, even some of the legislative power dealing with the Bank of Finland was transferred from parliament to the Bank Supervisors (Kastari 1955:1, 69, 80)

'The Bank of Finland acts under the guarantee and jurisdiction of parliament.' This constitutional statement is in practice realized in the following manner: Following a general election, which normally takes place every fourth year, parliament elects nine supervisors of the central bank. Three of them are appointed to the smaller organ, the 'Restricted Body of Supervisors'. The President of the Republic appoints, on the recommendations of the Bank Supervisors, a chairman and five other members to the Board of Management. The chairman is called the Governor of the Bank of Finland (e.g. Onikki 1978:7, 15, 18, 778-785).

The position of the Bank of Finland has been considered by many lawyers and historians to be exceptionally independent compared to the position of the central banks in many other countries (e.g. Schybergson 1914; Kastari 1955; Meinander 1962; Pipping 1961 and 1969).

The autonomy of the Bank of Finland is based on two premises. First, parliamentary supervision via the Bank Supervisors is weak due to the fact that the

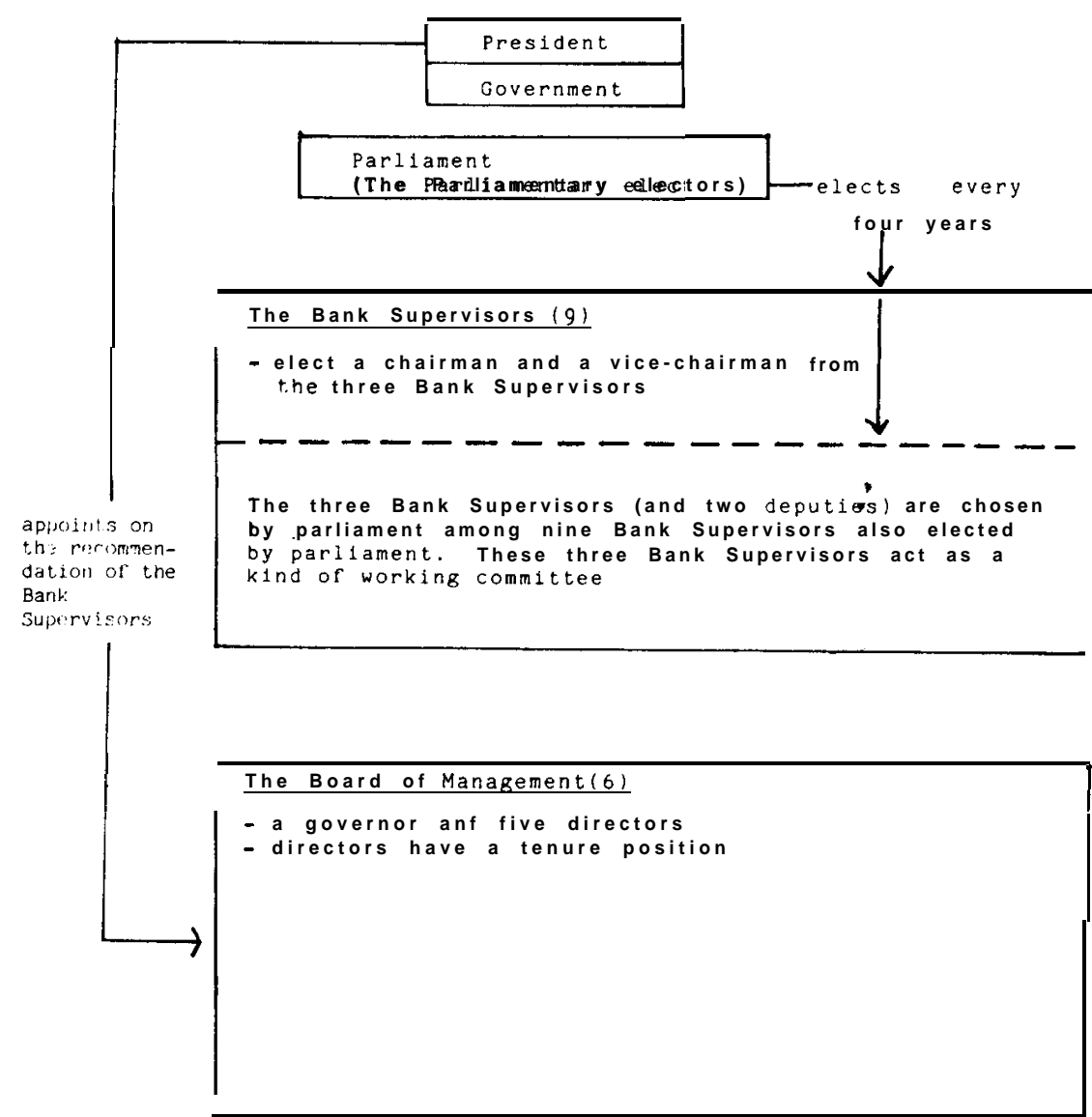

Fig. 2. The Central Bank in relation to the main political institutions in Finland.

supervisors are not responsible to parliament for their policy. Parliament, for example, has no way of withdrawing an appointment already made. Secondly, the Bank Supervisors, though formally superior to the Board of Management, do not have overall authority in relation to the decision-making powers of the Board of Management. The issues in which the Bank Supervisors have control are limited by legislation to specific questions only. In addition to this, the independence of the Board of Management is strengthened by appointing the members of the Board as tenured civil servants (Onikki 1982:844-845; Kastari 1955:85-92; Vesanen 1973:72-82)

\section{Norway}

In Norway, parliament appoints the Bank Supervisors together with three of the five members of the Board of Management for a period of six years. Two other 


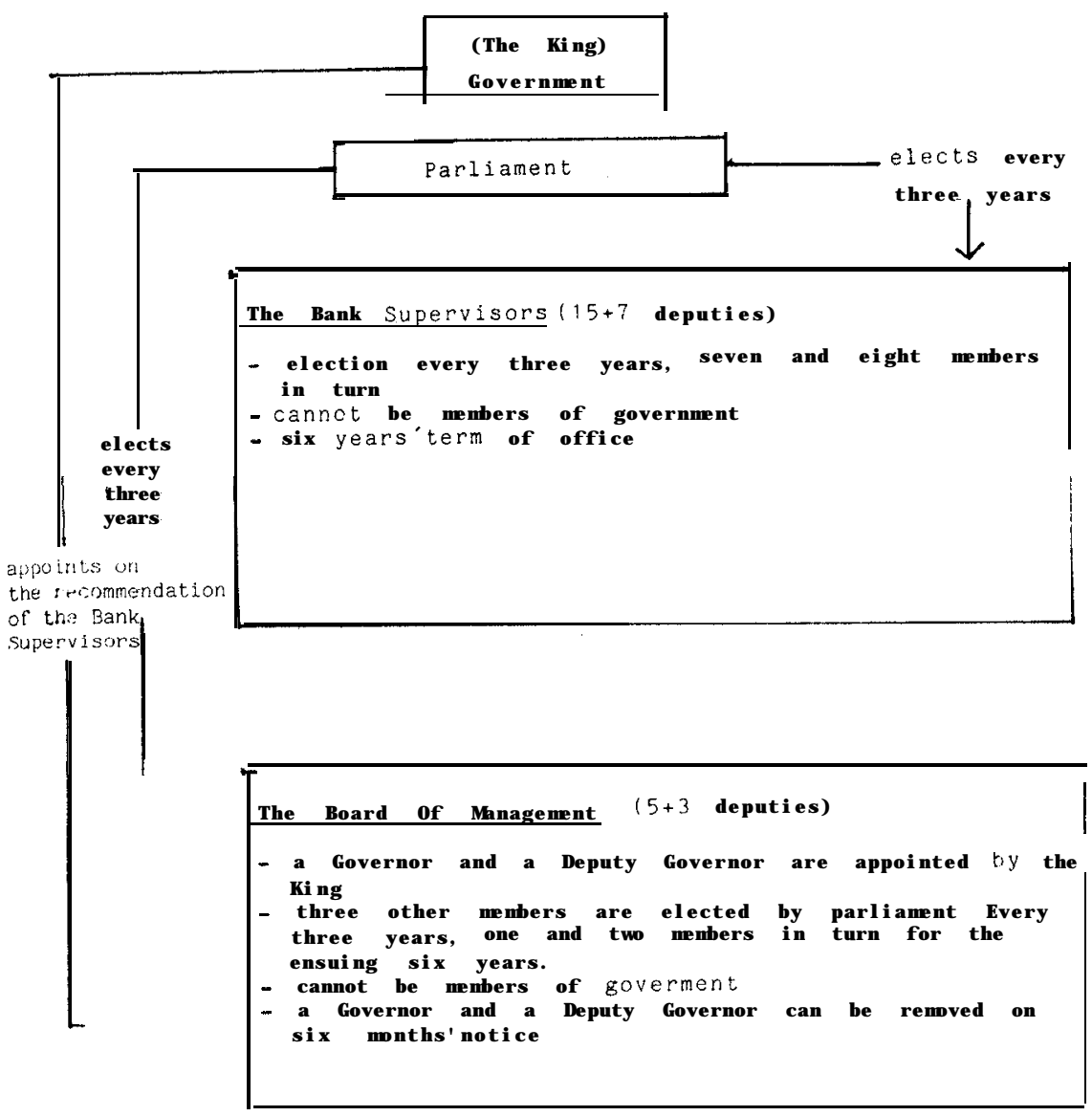

Fig. 3. The Central Bank in relation to the main political institutions in Norway.

members of the Board - a chairman and vice chairman - are appointed by the government. The supervisors are responsible to parliament and have to vacate their posts if at any time they do not have parliamentary support. The mandates of the directors can also be withdrawn. In the Norwegian system, political supervision of the central bank is very strict (Bahr 1980:153-157; Wold 1972 and 1979; Østerud 1979; Smith 1978; Jahn, Eriksen, Munthe 1966; Thunholm 1969).

\section{Sweden}

In Sweden, the Bank Supervisors comprise six members appointed by parliament and one by government who acts as chairman. The Bank Supervisors elect from their own ranks the Governor of the Bank, the deputy governor, freely elected, and two members also from their own ranks. The Board of Management consists of one advisory member within the bank, too (Petren, Ragnemalm 1980:173-174 and 233-234; Lindh 1963:312).

The Bank Supervisors are responsible to parliament and have to vacate their posts any time parliament expresses a lack of confidence. The government also has the right to withdraw a representative from the Supervisors. The Board of Management acts under the supervision formulated. Only the vice governor and the section director have the status of tenured civil servant. The structural possibilities of parliament and government to control the central bank are considerable. Authorized interpretations on Swedish legislation emphasize the coordination of the central bank's activities with the government's economic policy (Petren, Ragnemalm 1980:233-234).

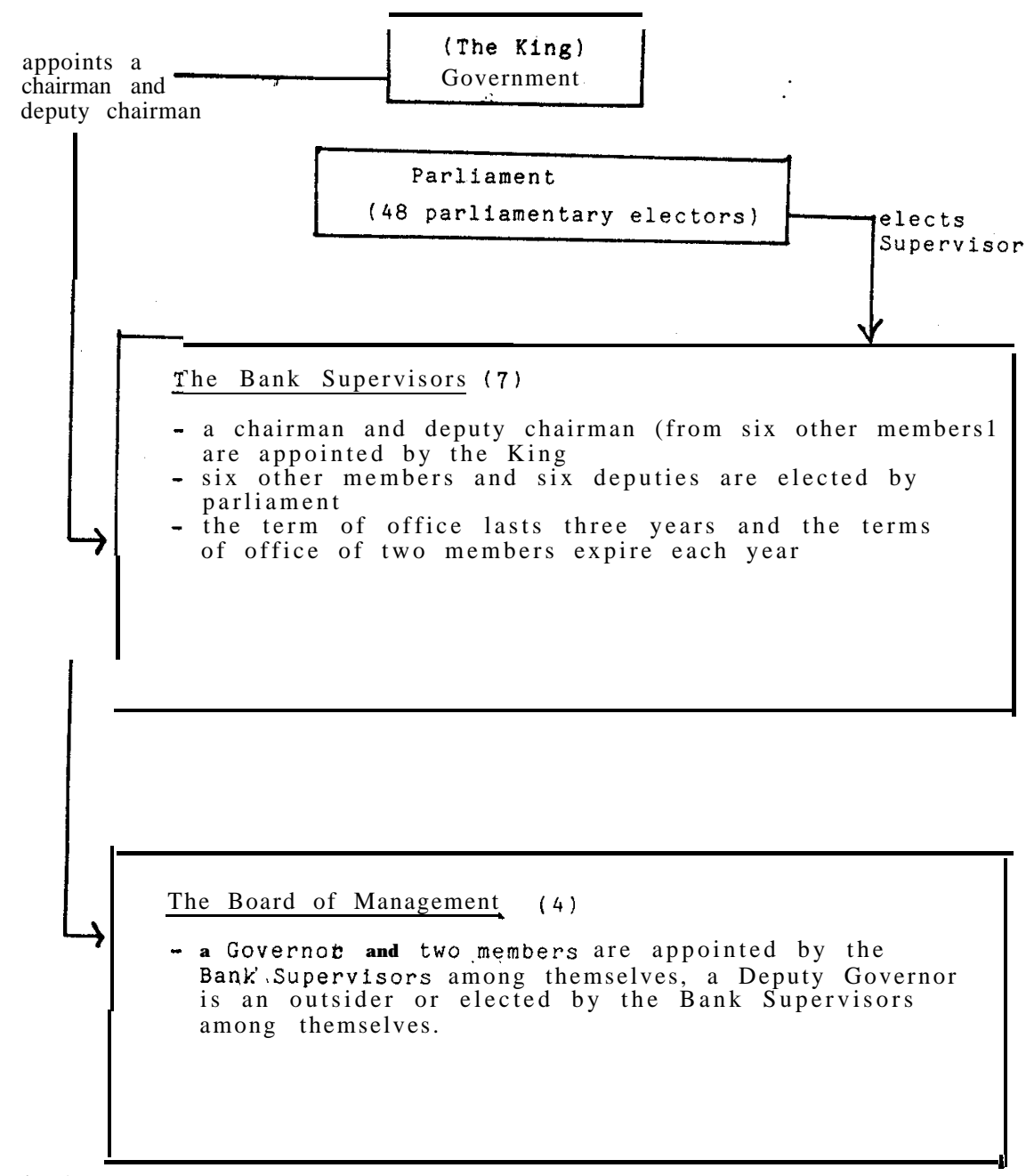

Fig. 4. The Central Bank in relation to the main political institutions in Sweden. 


\section{Monetarism and Keynesianism}

The central bank's traditional task is to supply the economy with means of payment and to keep the monetary system stable, which usually means taking measures against inflation (e.g. Aufricht 1965:13-27). The central bank may have many other functions as an active agent of economic policy and policy planning. The role of the central bank becomes especially important if the economic policy doctrine, i.e. monetarism, is followed. Monetarism is an alternative approach and the most serious challenge to Keynesian thinking. Keynesianism in its numerous modifications has dominated theoretical discussion in economics and economic policy planning since the great depression of the 1930's (Mayer 1978). Although the main features of Keynesian economic policy are commonplace, I shall nonetheless summarize some of the key principles.

In Keynesianism, market forces as a main mechanism steering economic development are not challenged. The state, however, has been given an important role as a balancer of economic fluctuations through the public sector. Public investmen and consumption should be increased during periods of unemployment and depression to stimulate the economy, and cut back during boom periods to reduce inflationary tendencies.

The basic doctrine in monetarism is that fluctuations in the quantity of money are the dominant cause of fluctuations in the economy. Therefore regulation of the quantity of money is a central measure in economic planning and policy (e.g. Laidler 1980; Thygesen 1977: 62-80)

Thomas Mayer lists a number of characteristics of monetarism as a paradigm in economics: the quantity theory of money, the proposition that changes in money stock are the dominant determinant of changes in money income, use of changes in the money stock as a means of economic policy, belief in the inherent stability of the private sector and dislike of government intervention and a relatively greater concern about inflation than about unemployment (Mayer 1978:1-46). A further proposition characterizing monetarism is the fact that the central bank has the power and responsibility to regulate money supply (e.g. Bronfenbrenner 197851).

Monetarist and Keynesian economic policies are distinct in their reaction to the public sector. Keynesianism presupposes, per definition, a relatively large public sector. Macro economic regulation by Keynesian means would in fact be technically impossible if the public sector played a very minor role in the total economy (Keynes 1936).

Monetarism, however, does not depend on the public sector in the same way. The control of money supply can be realized despite the size of the public sector. Monetarism often seems to mean a restoration of economic liberalism. The tasks of the public sector should be transferred as far as possible to the market. Many monetarist authors seem to openly support an ideological stance in favour of laissez-faire capitalism. Milton Friedman, the Nobel-prize winner and leading economist of the present monetarist school, appears, in some of his works, to take a stand against all central guidance of the economy, both monetary and fiscal (e.g. Friedman 1965:4 and Friedman, Friedman 1980:36)

\section{Keynesianism and monetarism in Scandinavian economic policy}

Of the Nordic countries, Sweden and Norway have been the vanguards of Keynesian state interventionism since the Great Depression of the 1930's (e.g. Landgren 1960; Osterud 1972 and 1979; Uusitalo 1976). In Denmark, Keynesianism has never received the same dominant status as in Sweden and Norway; Finland has never applied Keynesian economic policy in the sense of the other Scandinavian countries.* Finland's anti-Keynesianism, or rather innocence in respect to Keynesian economic policy principles, is surprising. In other respects Finland has applied very similar social policy principles, especially since the Second World War, as other Scandinavian countries. The volume of the public sector in Finland is somewhat, though not crucially, below the level of the other Scandinavian countries (Fig. 5). General welfare policy principles are similar and much legislation in many areas is in line with other Scandinavian countries.

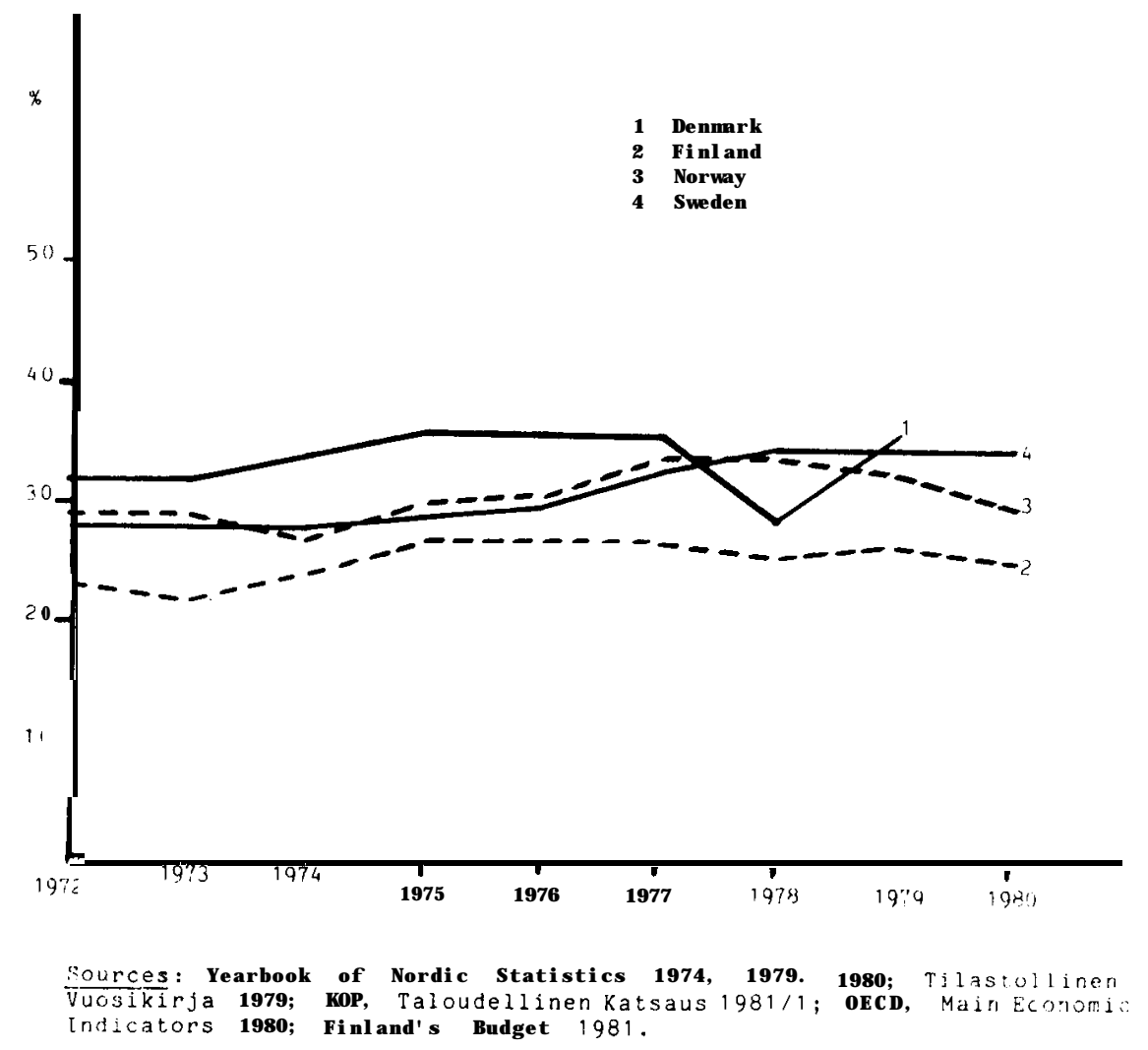

Fig. 5. Central government expenditure as a percentage of gross domestic product in the Nordic countries in 1972-1980. 
Variation in budget deficit or surplus is the most commonly employed means of operationalizing Keynesian principles in economic policy. According to monetaris ideals, the state budget should be in balance annually. In this way, the economic activity of the public sector is neutral and does not adversely affect the factors that aim to balance the economy. In the Nordic countries the budgets were balanced in the following manner ${ }^{3}$ (Fig. 6A, B).

Budget deficits in Sweden and Norway have been larger than in Denmark and Finland. Finland gives the impression of consciously keeping her budget in balance without paying undue account to the development of unemployment. In Denmark, despite remarkably high unemployment figures, the budget regularly shows a balance, and often a surplus. The avoidance of dependence on loans has evidently been a well established principle in Danish economic policy, and has been followed even although the engineers of Danish economic policy have been well aware of the Keynesian ideas followed by, for example, Sweden since the 1930's (e.g. Kapmann 1957;305-321). Finland's budgetary policy is closest to monetarist ideals. Next comes Denmark. This is in line with the relative importance paid to monetarist measures in Danish economic policy in general (Svendsen et al. 1968:31-39 319-331).

Full employment is an overt goal in Keynesian economic policy, but not so much in monetarism. Even the concept of full employment is avoided; natural unemployment is referred to instead. Natural unemployment is a concept linked to discussion about the so-called Phillips curve: the inevitability of a certain degree of unemployment to avoid wage inflation ${ }^{4}$ (e.g. Friedman 1975).

It is not necessarily the case that Keynesian economic policy, operating with 'full employment' as a central concept, in fact leads to a lower degree of unemploymen than monetarist economic policy. It can be supposed, however, that an economic policy utilizing the concept 'natural unemployment' also influences the way unemployment is regarded. 'Natural' as a concept cannot be interpreted technically, only by referring to the existing state of relations of economic parameters. The very vocabulary of Friedmanian, as well as Keynesian or any other paradigm of economics, has ideological functions, latent or manifest.

In Keynesian tradition, with full employment as an explicit target, unemployment is per definition seen as a social evil. This is not the case in monetarism, with a relatively greater concern about inflation than about unemployment (e.g. Mayer 1978:2, 37-39). Unemployment statistics in the Nordic countries seem to correlate with the relative importance of the monetarist measures in each country (Fig. 7). The general level of unemployment has been higher and the variance of unemployment remarkably stronger in Denmark and Finland than in Norway and Sweden. These differences can be interpreted possibly as a result of structural features in the Danish/Finnish economy that are different from the Swedish/Norwegian economy. Structural features, e.g. the traditional dependence of the Finnish economy on the world market for wood products, no doubt cause variation in employment figures. The Swedish economy, however, is partly vulnerable to the same world market. In addition to this, the Finnish economy has had a large trade with the Soviet Union as a market-balancing factor. The Danish and Finnish economies are structurally very far from each other, Denmark being the earliest, Finland the latest urbanized and industrialized of the Nordic countries (e.g. Pöntinen

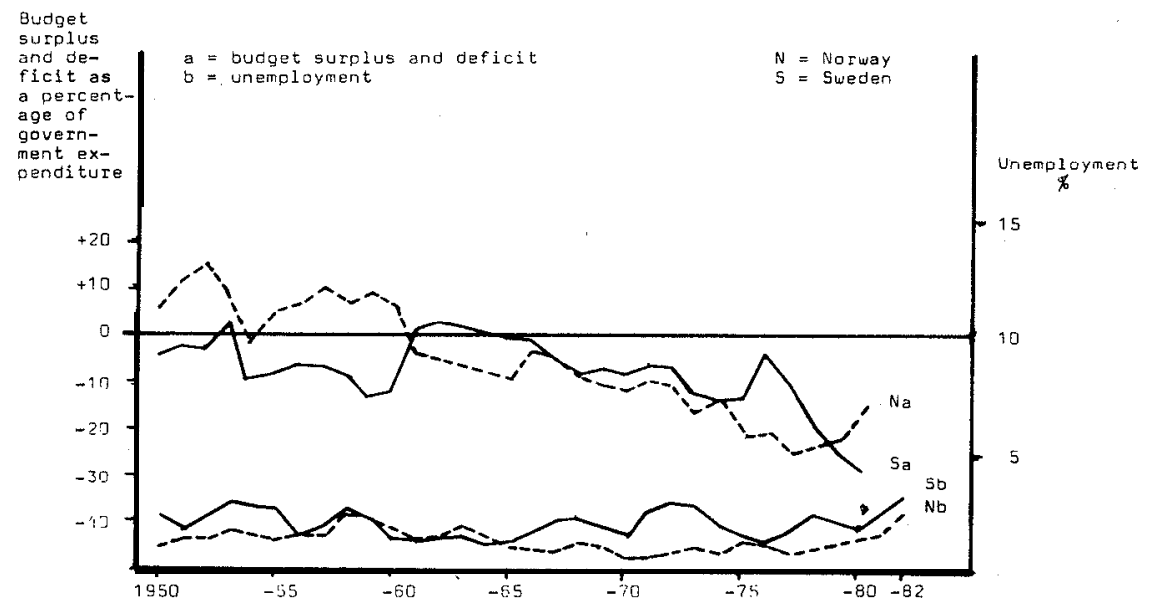

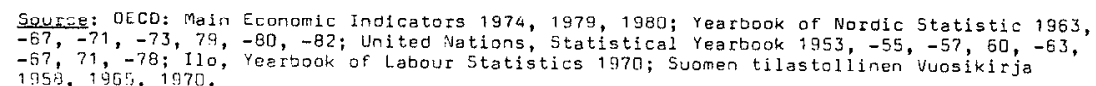

Fig. 6A. Budget surplus and deficit as a percentage of government expenditure in Norway and Sweden 1950-1980 (Year 1980: voted estimated adopted by Parliament) and unemployment Sweden 1950

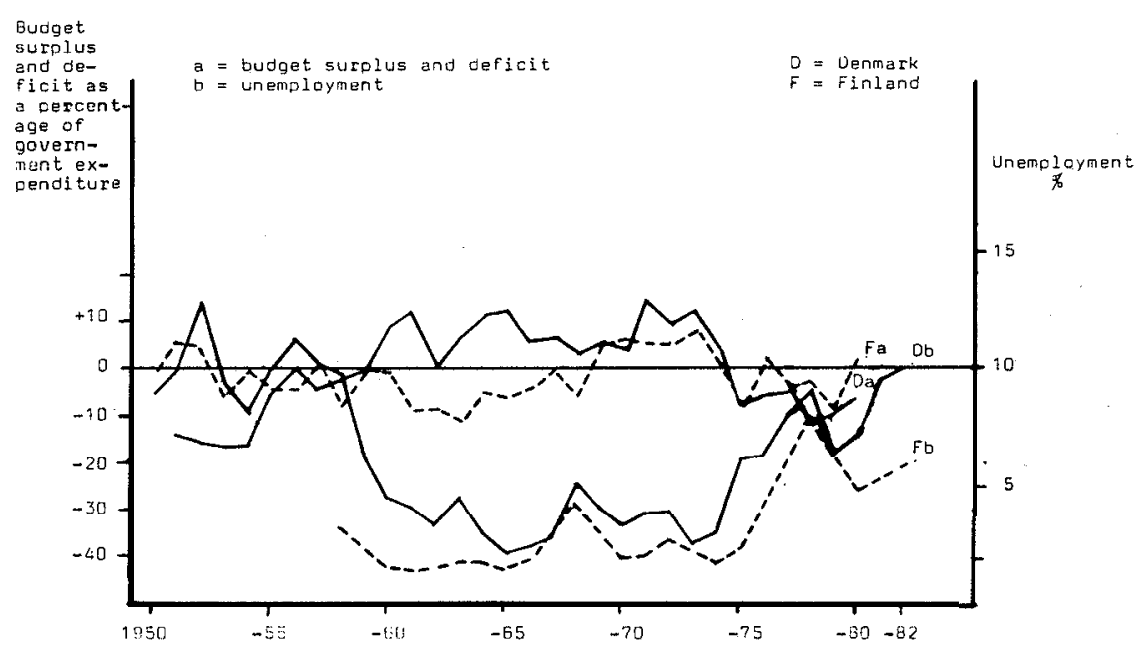

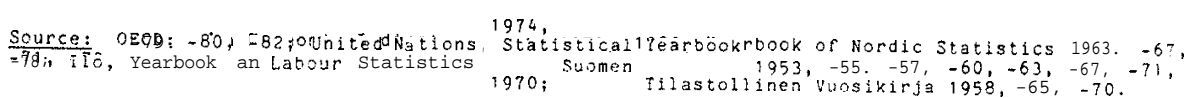
Fig. 6B. Budget surplus and deficit as a percentage of government expenditure in Denmark and Finland 19504980 (Year 1980: voted estimated adopted by Parliament) and unemployment 19504982. 


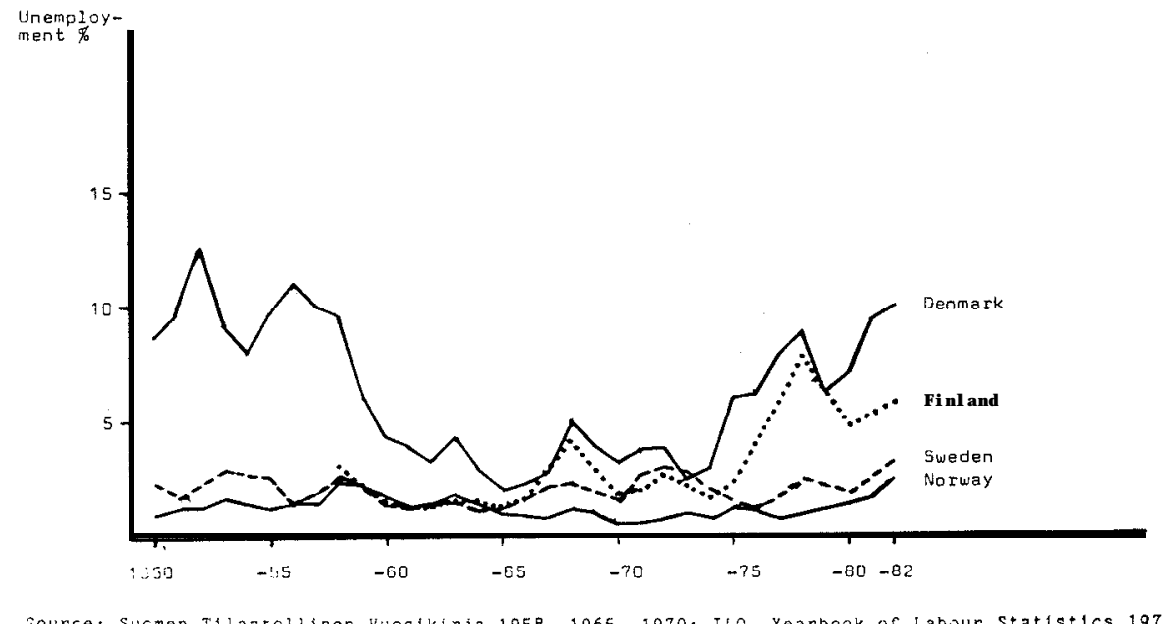

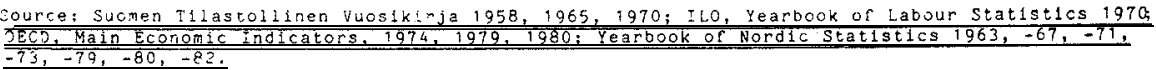

Fig. 7. U nemployment in the Nordic countries, 1950-1982.

1983:46). There are no self-evident structural reasons for unemployment being higher and varying more in Denmark and Finland than in Norway and Sweden.

In the 1970's, Finland has relied on monetarist rather than fiscal means. Finland's monetarism should not be regarded as conforming with the ideal of a country applying monetarist principles in general. As mentioned above, Finland has a relatively large public sector and a well developed welfare policy. Furthermore, the ideal model of monetarism presupposes antipathy to an activist stabilization policy, monetary or fiscal, and antipathy to wage and price controls (e.g. Laidler 1980; Friedman, Friedman 1980:36). These features do not adapt to the Finnish situation, because Finland has a well developed collective bargaining system with the state keenly involved by way of corporative mechanisms.

Finland's economic policy has never been in any respect a laissez-faire liberalism. Instead of regulation of the volume of government budget, other measures have been employed - principally monetarist. The role of the central bank in the Finnish economy is dominant. The monetary tools available are various; regulation of the bank's central bank finance, cash reserve deposits, the call money market, interest policy, credit policy guidelines, exchange rate policy, regulation of foreign finance, direct central bank credits to various sectors in the economy, etc. (Puntila-Airikkala 1978:11-18).

The Central Bank of Finland has steered the money market mainly by putting quantitative limitations on central bank loans to other institutions in the banking system. The amount and terms of the commercial banks' debt to the central bank are the main steering instruments of the central bank. If a commercial bank exceeds the set limits, the central banks' rate of interest for the loan increases. When the rates which the commercial bank can charge its customers are regulated, the commercial bank cannot pass the 'fine rate' of the central bank down to its customers. This situation reduces the profitability of the commercial banks and can actually render them totally unprofitable. When the demand for money from the commercial banks' customers is high, the loan limits set by the central bank are customarily exceeded in spite of declining profit margins.

The difference between the normal limits of central bank loaning and the quantity of central bank loans exceeding these limits is a valid measure in the Finnis monetary system accounting for the scarcity of money in the economy and the strictness of the monetary policy executed by the central bank. Monetarist steering by the central bank in Finland according to the indicator described above has been as follows (Fig. 8). Since 1979, regulation of the bank's central bank finance has been partly superseded by the increasing utilization of the call money market and cash reserve deposits. The new arrangements increase rather than decrease the role of the central bank as a principal institution of economic planning and guidance (Bank of Finland 1979:17-20).

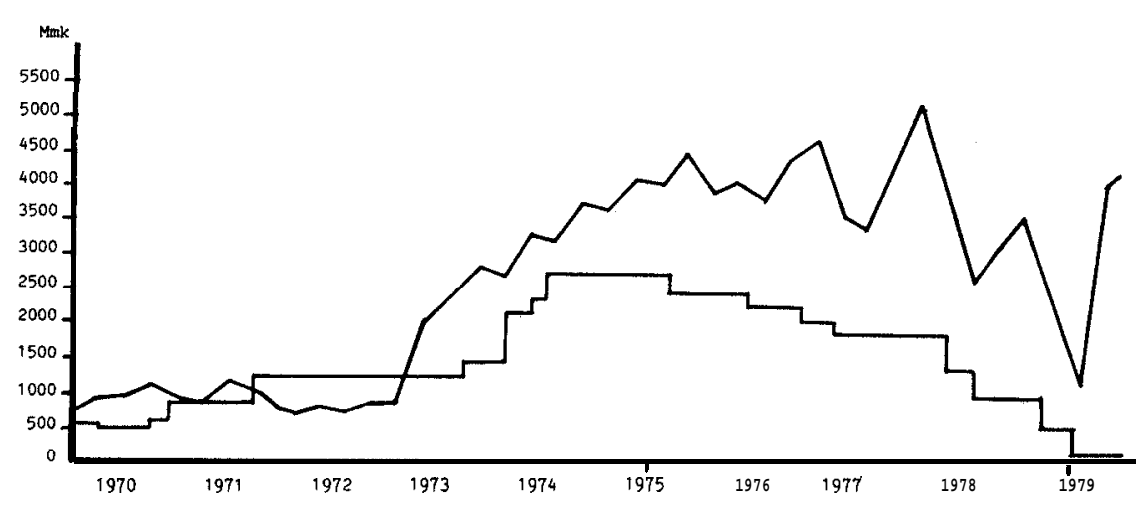

1. Total central bank debt

2. The quotas

Bank of Finland, Year Book 1977, 1980.

Fig. 8. Commercial Bank, Central Bank financing, 19704979 in Finland.

\section{A strong central bank or a weak government?}

Central political institutions utilized in bourgeois democracies are the legislative body and the government in its traditional form. Keynesianism is based on the principle that the volume of the public sector is to a large extent guided by the means of budgetary policy. This endows the government with the main responsibility for economic co-ordination.

The constitutional status of the government and the legislature is one of the institutional presuppositions of economic policy. Keynesian guidance demands a' relatively strong political government with sufficient support at the legislature. There are constitutional reasons why in Finland even a majority government is more limited in practising flexible and effective economic policy than other Scandinavian governments. Utilization of some of the measures necessary for Keynesian 
type economic guidance demands a stipulated majority in the Finnish parliament; this is not the case in other Scandinavian countries (e.g. Kastari 1977:95-101)

One reason for this is the unique historical background to many of the articles of the Finnish Constitution following a violent class struggle in the form of the civil war in 1918. The victorious bourgeoisie wanted to exploit the prevailing political situation to secure permanent guarantees against the demands of the militarily defeated but still potentially powerful working class. Endowing the president with far-reaching executive power was one way of restricting the power of the parliament and the cabinet subordinate to it (e.g. Puntila 1971:120-122, Kastari 1977:51).

The immediate interests of the bourgeoisie, as seen during the period of constitutional reforms in the 1920's after the civil war, and the demands of the late developed capitalism are hardly parallel. Political development in Finland, especially since the 1960 's, has provided numerous examples of this. Parliament has had to find means of circumvention in order to increase the government's possibilities for economic manoeuvring. Legislation has therefore been brought in increasing the power of the cabinet for a certain period concerning economic policy matters. Another way of by-passing the constitutional restrictions of the government in economic policy has been the active role of the president in critical economic policy matters. Presidential intervention in economic policy has been due to the relatively weak status of the government.

The role of the Constitution should not, however, be overemphasized. The Finnish Constitution does not put overwhelming restrictions on a majority government running a Keynesian economic policy. The budget, for example, can be balanced at a higher or lower level by a simple majority vote in parliament.

A relatively stable majority government predisposed to practising market-balancing is a prerequisite for a Keynesian type fiscal policy. From the depression up until the 1970's, Sweden and Norway have enjoyed stable social democratic rule. The political constellation in Finland has been very different, the crucial distinction being that the social democratic labour party has been historically split into social democratic and communist factions. The development, as such, weakened the labour movement, and was strengthened further by periodic discrimination against the Communist Party.

Finland became a country governed mainly by coalition cabinets, the main parties being the social democrats and the agrarian centre, with periods of bourgeois minority governments. Finland's political structure has perhaps not provided a favourable basis for Keynesianism. Even the very time span of the market situation demands longer term cabinets than Finland has had at times. In Sweden and Norway, long periods of stable social democratic rule have favoured Keynesian economic policy.

Denmark's political history seems to share some common characteristics with Finland's. Denmark has been governed by coalition and sometimes by minority cabinets. The social democrats in Denmark have never achieved the same hegemony they have in Sweden and Norway, and very often have had to govern in coalition with bourgeois parties. The country has also experienced remarkably long periods with the labour party in opposition. So the political conditions for a stable Keynesian fiscal policy have been less favourable in Denmark than in Norway and Sweden (e.g. Winding 1967:375-377; Banks, Overstreet 1980:138-140).
Social democracy, Keynesianism and the institutional status of Nordic central banks

According to the material presented, the Nordic countries with a strong central bank autonomy have applied a more monetarist oriented economic policy. whereas those with a weaker central bank autonomy have applied a Keynesian economic policy.

A straightforward interpretation of the monetarist versus 'Keynesian' orientation in Scandinavian economic policy would be the different power positions of the Scandinavian central banks. If a central bank has more independent status than the government and parliament, then also monetarist measures become more part of economic policy.

This interpretation is open to the question of power's origin. The political institutions, government and parliament are the primary søurces of a central bank's juridical status. If the central bank is politically more controlled in some countries and has more autonomy in others, this is only an indicator of the political principles accepted by the parliament and government?

Keynesianism is strongly associated with the long term social democratic regimes in Norway and Sweden. Though social democrats have been an important political factor in Denmark and Finland too, they have never received the same hegemony there. The causal relationship could be that social democrats applying Keynesian type economic policies have also established the politically more controlled central bank system of Norway and Sweden. This is an alternative to the hypotheses concerning the importance of the institutional status of the central bank compared with the economic policy applied. This counterargument, however, gets no empirical support from the history of the Nordic central banks. Differences in the juridical status of the Nordic central banks are not a result of social democratic policy in Sweden and Norway. The differences between the Nordic central banks go much further back in history than the social democratic regimes of Norway and Sweden or the diffusion of Keynesian principles to the Nordic countries. The banking laws of the nineteenth century (in Norway 'Lov om Norges Bank' was enacted on 23.4.1892, in Sweden 'Lag for Sveriges Riksbank' was enacted on 12.5.1897) reflect the same difference in the status of the central banks as has existed up to the present time. Social democrats came to power in the early 1930's in Sweden and Norway. At that time, Keynesianism was not regarded as social democratic but as a basically bourgeois doctrine to be utilized as a temporary measure for the very first years of the labour party regime. The close ideological connection between Keynesianism and Swedish or Norwegian social democracy was established considerably later as a result of the economic success in these countries under the Keynesian umbrella (e.g. Landgren 1960).

\section{Social determinants of economic reality}

The most plausible theoretical interpretation of our findings is likely to be found not in economics or politics but rather in the sociology of knowledge. The structural position of the central banks can surely be changed by the legitimate political institutions in accordance with the constitutional procedures. The problem is that 
the position of the central bank and its policy is very often regarded as technical and not political. Central bank autonomy may have ideological consequences favouring this kind of development. The traditional autonomy of the central bank strengthens the ideology of the monetary policy's character as a sphere of technical expertise and knowledge. The central bank has the function of an ideological apparatus of the state (e.g. Althusser 1970; Habermas 1981).

An example of the possible ideological role of the central bank is perhaps the fact that Finnish labour parties have made no political demands to reduce the central bank's traditional autonomy. However, close coordination of central bank activities with government economic policy was needed to make Keynesian type economic policy possible. The connection of the central bank's structural status with the prevailing economic ideology can also be understood in the light of some theses on the sociology of knowledge.

The choice of measures in economic planning is normally considered to be made on the basis of information available on the prevailing conditions and future prospects for economic development. In macro-economic planning, the main economic indicators used are: the growth rate of GNP, the rate of inflation, the degree of unemployment, and the balance of payments in foreign trade. The relative weight given to these kinds of indicator can vary considerably. It is not surprising that the central bank is more worried about inflation and the balance of payments than it is about the degree of unemployment. The means of economic policy under the central bank's own control are naturally monetarist ones. Furthermore, the whole realm of economics and the need for economic guidance is probably regarded differently by the central bank and the government.

Constructing social reality and the determinants of this process is a key problem in understanding sociology. It could equally well be asked how economic reality is constructed? Or rather how economic reality as a part of social reality is built up.

The sociology of knowledge deals with the structural determinants of knowledge. In this case, how economic reality is determined by the quality of available information and how this quality of information is determined by the social structure. When a sociologist determines economic reality, he is similarly dealing with the social structure of information production and decision-making economic institutions, the relations of these institutions and their interaction (e.g. Curtis, Petras 1972; Merton 1972:342-372; Berger, Luckmann 1967).

One of the most plausible ways of summarizing the social determination of knowledge is summed up by Karl Mannheim: The position of the producer of knowledge in history and in the social structure defines the quality and the nature of the knowledge (Mannheim 1965).

We need to define what the term 'social structure' means in this connection. The banking system, the government and parliament are social institutions with an important role as elements of social structure in a capitalist state. The state has a key role in macro-economic guidance. The state is usually defined in standard sociology textbooks as 'a social institution having a monopoly on the legitimate use of force' (Weber 1976:824). It would be more appropriate to define the state, in this context, as a social institution which has a legitimate monopoly to produce money to sustain the monetary system within a certain geographical area. The state pursuing a capitalist economy might be better characterized via the monopoly of a monetary system than through the army or police as a means of the legitimate use of force. ${ }^{5}$

\section{Summary and conclusions}

This paper has considered the differences in the economic policies of the Scandinavian countries. The commonsense interpretation that distinct economic situation demand different policies has been challenged by reference to an alternative interpretation. The policies have varied not because the demands of the economy have been different, but because the demands of the economy have been regarded as being distinct.

Comparison of the status of four Scandinavian central banks shows that, Sweden and Norway, central bank autonomy is less than in Denmark and markedly less than in Finland. Norway and Sweden are countries which have applied mainly fiscal 'Keynesian' means in their economic policies. The Keynesian tradition is weak in Denmark and almost totally absent in Finnish economic policy. The stron status of the central bank correlates with the monetarist measures employed in macro-economic policy.

According to the material presented, the strong status of the central banks in Denmark and Finland reflects the political history and political structure of these countries, and not the actual needs of macro-economic policy and economic planning.

In Norway and Sweden, Keynesianism has been closely connected with stron and long-term social democratic rule. In Denmark and Finland the role of social democracy has been important but not as dominating. The origin of the differences in the structural status of the Scandinavian central banks cannot be explained by the various roles of social democracy. Differences in the structural status of the Scandinavian central banks existed as early as the nineteenth century, long before social democracy began to play a dominant role in the government policy of any Scandinavian country or before the birth of Keynesianism and its diffusion to Scandinavia.

In this paper the role of the central banks has been studied as an agent of economic decision-making. Support is given to the hypothesis that the institutional position of the principal organizations of the state and the power relations between them are relevant structural determinants of constructing the economic reality which further justifies the economic policy. The countries in which the central bank exercises a strong juridical and political position tend to define the economic situation as demanding principally monetary measures. These countries may apply mainly monetarist means in their economic policy. All four Scandinavian countrie have small open economies influenced by the same international market situation. There is no reason to believe that the objective economic situation systematically demands Keynesian type economic measures in some countries and monetaris measures in others.

The choice between monetarist and financial ('Keynesian') measures is relevan to many features in society; not least to approaches on the problems of unemployment. Scandinavian monetarism represented in Danish and even more in 
Finnish economic policy has not however meant denial of the welfare State principles in social policy. In this respect the Scandinavian 'monetarists' and 'Keynesians have been very likeminded.

\section{Notes}

1 The position of the ruble economy was further weakened as a result of the Swedish currency remaining a valid means of currency in Finland for several decades after the political union 1809.

2 A revealing feature of Finland's policy during the depression was that the national debt was Finnish State is on a thoroughly sound basis' (Suviranta 1931:32. See also Karjalainen 1959:122-140)

3 The 1940's and even the first years of the 1950's was the period of war and reconstruction economy in the Scandinavian countries too. It is therefore reasonable to restrict the more
systematic comparison of Scandinavian market policy to the period when the war and systematic comparison of Scandinavian mark
reconstruction economy had already finished.

4 The basis of the Phillips curve discussion is the correlation found between unemployment and the fluctu

1958:283-299).
Max Weber mentions as an extreme theoretical example the case when der Rechstaat has a laissez-faire economy to the degree that even producing money and sustaining the monetary system is transferred to the private sector (Weber 1976:24)

\section{References}

Althusser, Louis. 1970. Ideologié et Appareils Idéologiques d'Etat. La Pensée. N:0 151. Paris. Mai-Jun

Asp, Thore. 1898. Die Geschichte des Finländischen Bank und Münzwesens bis 1865. Strassburg: C. Buchdruckerei \& J. Goeller.

Aufricht, Hans, 1965. Comparative Survey of Central Bank Law. The London Institute of World Affairs. London: Stevens \& Sons.

Bahr, Henrik (ed.). 1980. Norges lover 1685-1979. Det Juridiska Fakultetet. Oslo: Grøndahl et Søn 1980.

Bank of Finland: Yearbook 1977, Helsinki 1978. Yearbook 1979, Helsinki 1979. Yearbook 1980, Helsinki 1981.

Berger, Peter L. \& Luckman, Thomas. 1967. The Social Construction of Reality. New York: Anchor Books.

Bronfenbrenner, Martin. 1978. Thomas Mayer on Monetarism. In Thomas Mayer (ed.), The Structure of M onetarism. New York: W. W. Norton \& Company.

Budgets of Denmark, Finland, Norway and Sweden, 1971-1980.

Budget of Finland, 1981, Helsinki 1980.

Curtis, James E. \& Petras, John W. (ed.) 1972. The Sociology of Knowledge. New York,

Washington: Praeger.
von Eyben, W. E. \& Skovgaard, Henning (ed.) 1983. Karnous Lousamling. København Karnovs forlag.

Finansministeriet. 1956. Samarbejdsproblemer i Danmarks O konomiske Politik. Betaenkning Nr. 154. København.

Friedman, Milton. 1965. A Program for Monetary Stability. New York: Fordham University Press.

Friedman, Milton. 1975. Unemployment versus
London: The Institute of Economic Affairs.

Friedman, Milton \& Friedman, Rose, 1980. Free to Choose. Harmondsworth, Middlesex: Priedman, Milton \& Friedman, Rose, 1980. Free to Choose. Harmondsworth, Middlesex:
Penguin Books.

Frank, Jürgen. 1981 (1968). Teknik und Wissenschaft als 'Tdeologie'. Edition Suhrkamp. Frankfurt am Main: Suhrkamp Verlag.
Hurwitz, Stefan \& von Eyben, W. E. (ed.). 1972. Karnovs Lovsamling. København: Ottendr udgave.

ILO. 1970. Yearbook of Labour Statistics. Geneva.

Jahn, Gunnar, Eriksen, Alf \& Munthe, Preben. 1966. Norges Bank gjennom 150 år. 0 slo Norges Banks Seddeltrykkeri.

Jorges Banks Sect. Sumneus oikealle (1923-1926). Tommila, Päivio (toim.) Kaksivuo-

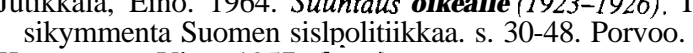

Kampmann, Vigo 1957. Statsfinanserneog Kapitalmarkedet National-okonomisk Tidsskrift 1957 (305-321). København: National-Okonomisk Forening.

Karjalainen, Ahti. 1959. Suomen Pankin rahapolitikan jau Suamen Aht. 19. Suomen Pankin rahapolitiikan ja valtion talouden väliset suhteen

Suomen Pankin taloustieteellisen tutkimuslaitoksen julkaisuja. Sarja B:21, Helsinki,
Kastari, Paavo. 1955. Suomen Pankin erikoisasema valtiokoneistossa. Suomalaisen Lakim syhdistyksen julkaisuja B-sarja, no 68, Vammala.

Kastari, Paavo. 1977. Suomen valtiosääntö. Suomalaisen lakimiesyhdistyksen julkaisuja BKastari, Pavo. 1977. Suomen valtiosääntö. Suomalaisen lakimiesyhdistyksen julk
sarja no 179. Lainopillisen ylioppilastiedekunnan kustannustoimikunta. Helsinki.

Keynes, John Mayard, 1936. The General Theory of Employment, Interest and Money. Keynes, John
London.

KOP. 1981. Taloudellinen katsaus 1981/1. Helsinki.

Laidler, David. 1980. Monetarism: An Interpretation and Assessment Revised version of a paper presented at a conference held on July 24, 1980 in London, under the auspices of

Landgren, Karl-Gustav. 1960. Den 'Nya ekonomien' i Sverige. Ekonomiska studier, National-ekonomiska Institutionen vid Goteborgs Universitetet. Uppsala: Almqvist \& Wicksell.

Lindh, Sven. 1963. Sveriges riksbank; Janssens, Valery et al. Eight European Central Banks. New York.

Mannheim, Karl. 1965. Ideology and U topia. New York: Harcourt, Brace \& World.

Mayer, Thomas. 1978. The Structure of Monetarism. New York: W. W. Norton \&

Company.
Meinander, Nils. 1962. Penningpolitik under ett hundrafemtio \&r. Helsingfors: Finlands Bank Institut for ekonomisk Forskning, serie c 3 .

Merton, Robert K. 1972. Paradigm for the Sociology of Knowledge. In Curtis \& Petral (ed.) The Sociology of Knowledge. New York, Washington: Praeger.

OECD. 1974, 1979, 1980. Main Economic Indicators. Paris.

Olsen, Erling. 1962. Danmarks økonomiske historie siden 1750. Studier fra Kobenhavn Universitets Okonomiske Institut Nr. 3, København: G.E.C. Gads Forlag.

Onikki Erkki (ed.). 1982. Suomen laki II. Suomen Lakimiesliitto. Helsinki.

Petren, Gustaf \& Ragnemalm, Hans (ed.). 1980. Sveriges grundlagar och tillhörande författningar med förklaringar. Stockholm: Liber Förlag.

Phillips, A. W. 1958. The Relation Between Unemployment and the Rate of Change of Money Wage Rates in the United Kingdom 1861-1957. Economica.

Pipping, Hugo E. 1961. Från pappersrubel till guldmark. Finlands bank 1811-1877 Helsing fors: Suomen Pankki-Finlands bank.

Pipping, Hugo E. 1969. I guldmyntfotens hägn.Finlands Bank 1878-1914. Helsingfors: Finlands bank.

Puntila, L. A. 1971. Suomen poliittinen historia 1809-1966. Helsinki: Otava.

Puntila, Markku \& Airikkala, Reino. 1978. Monetary Policy in Finland. Financial Markets in Finland. Helsinki: Suomen Pankki-Finlands Bank.

Pbntinen, Seppo. 1983. Social Mobility and Social Structure A Comparison of Scandinavian Scienty and Social Structure. A Comp Countries. Commentationes Scientianum and Letters. Helsinki.

Schybergson, Emil. 1914. Suomen Pankki 1811-1911. Helsinki: Frenckellinkirjapaino-

Smith, Carsten. 1978. Statslivog rettsteori. 0 slo: Universitetsforlaget.

Suomen Tilastollinen Vuosikirja 1958, 1965, 1970. Helsinki: Tilastokeskus. Suviranta, Bruno. 1931. Finland and the World Depression. Supplement to the Bank of
Finland Monthly Bulletin No. 4, 1931. Helsinki: Valtioneuvoston kirjapaino. 
Svendsen, Knud-Erik, Hansen, Svend Aage, Olsen, Erling \& Hoffmeyer, Erik. 1968. 'Dansk Pengehistorie. Danmarks Nationalbank. Odense: Andelsbogtrykkeriet.

Thunholm, Lars-Erik. 1969. Bankuäsendet iUtlandet. Studierådet vid Affärsbankerna. Stockholm: P. A. Nordstedt \& Söners förlag.

Thygesen. Niels. 1977. The Scientific Contributions of Milton Friedman. Scandanavian Journal of Economics. No. 1, Stockholm.

United Nations. 1953, -55, -57, -60, -63, -67, -71, -76, -78. Statistical Yearbook, New York: Statistical Office of the United Nations.

Uusitalo Paavo 1976. Samhällsplaneringens m\&l och medel Stockholm: Almqvist \& Wicksell. Waris, Klaus. 1977. Markkakin on valuuttaa. Helsinki: Kirjayhtymä

Waris, Klaus. 1977. Markkakin on valuuttaa. Helsinki: Kirjayhtymá. J. C. B. Mohr (Paul Sienbeck).

Jesanen, Tauno. 1973. Finanssiorgaaneista ja markan kansainvälisestä perusarvosta. Helsinki: Suomen Lakimieslitton Kustannus Oy.

Winding, Kjeld. 1967. Danmarks Historie. København: Fremaeds Fokusbøger

Wold, Knut Getz. 1972. Norges Banks samarbeid med statsmaktene, bank Kristofer Lehmkuhl Forelesning, Bergen: Norges Handelshoyskole.

Wold, Knut Getz. 1979. Statsbankenes oppgaver børttas opp tilgrundig vurdering. Økonomisk revy 3.

Yearbook of Nordic Statistics, 1963, -67, -71, -73, -79, -80, -82. Stockholm.

Østerud, Oyvind. 1972. Samfunnsplanleggning og politisk system. O slo: Gyldendal Norsk

Forlag.

Østerud, Øyvind. 1979. Det Planlagte Samfunn. Oslo: Gyldendal. 